\title{
PENINGKATAN EKONOMI DESA MELALUI PENGELOLAAN LINGKUNGAN DAN POTENSI DESA DI DESA MEKAR RAHAYU KECAMATAN MARGAASIH KABUPATEN BANDUNG
}

\author{
Dadang Sudirno, Abdul Kholiq, Masduki Masduki, Umar Dani, \\ Dede Salim Nahdi, Hani Sri Mulyani, L. Suparto \\ Universitas Majalengka \\ dsudirno@unma.ac.id
}

\begin{abstract}
The importance of the role of society as a component of supporting the development of the nation, makes every community group has the obligation to continue to develop. Of these community groups, rural communities are the ones that are rarely touched by waves of development and growth because community development is currently dominated by developments in urban areas. Students as one of the components in society are demanded to be a party to bridge the development gap. In other words, the real manifestation that must be done by students is to help rural communities to develop existing capabilities within the community so that they can support equitable development without any gaps in the level of development between villages and cities.
\end{abstract}

Keywords: improvement, village economy, village potential.

\begin{abstract}
Abstrak
Pentingnya peranan masyarakat sebagai komponen penunjang perkembangan bangsa, membuat setiap kelompok masyarakat memiliki keharusan untuk terus berkembang. Dari beberapa kelompok masyarakat tersebut, masyarakat desa merupakan masyarakat yang paling jarang tersentuh oleh gelombang pembangunan dan pertumbuhan karena perkembangan masyarakat saat ini didominasi oleh perkembangan di perkotaan. Mahasiswa sebagai salah satu komponen dalam masyarakat dituntut untuk menjadi pihak yang menjembatani kesenjangan perkembangan tersebut. Dengan kata lain, wujud nyata yang harus dilakukan oleh mahasiswa adalah membantu masyarakat desa untuk mengembangkan kemampuan yang telah ada dalam diri masyarakat agar dapat menyokong pembangunan secara adil tanpa ada kesenjangan tingkat perkembangan antara desa dan kota.
\end{abstract}

Kata Kunci: peningkatan, ekonomi desa, potensi desa.

\section{Pendahuluan}

Pentingnya peranan masyarakat sebagai komponen penunjang perkembangan bangsa, membuat setiap kelompok masyarakat memiliki keharusan untuk terus berkembang. Dalam berbagai aktivitas pembangunan tersebut, setiap warga negara memiliki hak untuk terlibat aktif (Hermansyah, 2018). Dari beberapa kelompok masyarakat tersebut, masyarakat desa merupakan masyarakat yang paling jarang tersentuh oleh gelombang pembangunan dan pertumbuhan karena perkembangan masyarakat saat ini didominasi oleh perkembangan di perkotaan. Menurut UU ditambahkan pada UU No. 22 Tahun 1999, desa adalah kesatuan masyarakat hukum yang memiliki kewenangan untuk mengatur dan mengurus kepentingan masyarakat 
setempat berdasarkan asal usul dan adat istiadat setempat yang diakui dalam sistem pemerintahan Nasional dan berada di daerah Kabupaten. Mahasiswa sebagai salah satu komponen dalam masyarakat dituntut untuk menjadi pihak yang menjembatani kesenjangan perkembangan tersebut. Dengan kata lain, wujud nyata yang harus dilakukan oleh mahasiswa adalah membantu masyarakat desa untuk mengembangkan kemampuan yang telah ada dalam diri masyarakat agar dapat menyokong pembangunan secara adil tanpa ada kesenjangan tingkat perkembangan antara desa dan kota.

Tuntutan terhadap masyarakat agar terus berkarya dan berkreasi guna memberikan kontribusi positif bagi negara menjadi suatu hal yang harus diwujudkan dan hal tersebut akan dapat terwujud dengan nyata apabila masyarakatnya memiliki kesadaran, kemauan, dan potensi diri dalam setiap individunya.

Kegiatan Kuliah Kerja Nyata adalah suatu bentuk pendidikan dengan cara memberikan pengalaman empiris kepada mahasiswa untuk hidup ditengah-tengah masyarakat di luar kampus, dan secara langsung megajarkan kepada mahasiswa cara identifikasi masalah-masalah sosial kerakyatan. KKN dapat diartikan sebagai salah satu bentuk pengintegrasian kegiatan antara pengabdian kepada masyarakat, pendidikan dan penelitian yang dilaksanakan terutama oleh mahasiswa secara interdisipliner dan intrakulikuler dibawah bimbingan dosen dan masyarakat (Fida, 1997). Kegiatan KKN pada dasarnya merupakan kegiatan interaksi sosial yang melibatkan berbagai pihak. Dalam kegiatan KKN, kita akan menjumpai berbagai bentuk interaksi sosial, yang secara garis besarnya dapat diklasifikasikan ke dalam tiga pola atau bentuk interaksi sosial, yaitu : (1) interaksi antar orang perorangan; (2) interaksi antara orang dan kelompoknya, dan sebaliknya; dan (3) Interaksi antar kelompok (Gunawan, 2000:32). Kuliah kerja nyata secara langsung akan menunjukan keterkaitan langsung antara dunia pendidikan dan upaya perwujudan kesejahteraan masyarakat. Beberapa aspek yang diperhatikan dalam pelaksanaan kuliah kerja nyata adalah yang pertama keterpaduan pelaksanaan Tri Darma Perguruan Tinggi yang berupa pengajaran, penelitan, dan pengabdian pada masyarakat. Yang ke dua adalah pendekatan interdisipliner dan komprehensif yang artinya KKN bertolak dari permasalahan nyata masyarakat yang didekati menggunakan segala ilmu pengetahuan, teknologi dan seni yang susah, sedang, dan atau akan dipelajari. Yang ketiga adalah lintas sektoral, yang keempat dimensi dan luas dan pragmatis, yang kelima adalah ketelibatan masyarakat secara aktif, yang keenam adalah keberlanjutan dan pengembangan, dan yang ketujuh adalah bertumpu pada sumber daya lokal.

Berdasarkan dasar pemikiran inilah, kami sebagai Lembaga Pendidikan Perguruan Tinggi dalam hal ini Dosen dan Mahasiswa Universitas Majalengka dituntut untuk turut memberikan kontribusi bagi pembangunan desa dalam program Kuliah Kerja Nyata.

Kegiatan Kuliah Kerja Nyata ini memiliki beberapa tujuan yang akan dicapai yaitu:

a. Bagi masyarakat Desa Mekar Rahayu Kecamatan Margaasih Kabupaten Bandung:

1) Mendorong optimisme masyarakat dalam mengembangkan desa.

2) Mewujudkan masyarakat yang lebih kreatif dan positif dalam menata masa depan.

3) Mewujudkan kualitas sumber daya manusia yang berlandaskan Gotong Royong, Persatuan dan Kesatuan dalam Wadah Negara Kesatuan Republik Indosnesia. 
4) Menumbuh kembangkan motivasi masyarakat untuk berpartisipasi aktif dalam pembangunan, kepekaaan sosial dan penanganan persoalan-persoalan di Daerah Aliran Sungai Citarum

b. Bagi pelaksana kegiatan:

1) Sebagai wujud dari oreantasi Tri Darma Perguruan Tinggi yaitu pengabdian pada masyarakat.

2) Memberi pengalaman belajar tentang pembangunan masyarakat dan pengalaman kerja nyata pembangunan.

3) Memberi pengalaman kepada mahasiswa tentang kondisi yang terdapat pada masyarakat dan bagaimana hidup di tengah - tengah masyarakat dengan mengimplementasikan disiplin ilmu yang kita miliki.

4) Meningkatkan hubungan antara perguruan tinggi dengan Pemerintah Kecamatan, pemerintah Desa, dan masyarakat secara langsung.

Ruang lingkup kegiatan KKN-Tematik Citarum Harum Desa Mekar Rahayu Kecamatan Margaasih Kabupaten Bandung yaitu:

1) Sosial dan Pengelolaan Lingkungan

Kegiatan pemberdayaan masyarakat dalam pengelolaan lingkungan dimaksudkan untuk membantu meningkatkan kemandirian masyarakat dan memberdayakan potensi yang ada dimasyarakat maupun sumber daya alam yang belum dimanfaatkan dengan baik serta pengelolaan lingkungan di Daerah Aliran Sungai Citarum

2) Pembinaan dan Pengembangan UMKM

Kegiatan pengabdian pada masyarakat yang berupa penerapan hasil-hasil IPTEKS. Membentuk dan atau mengembangkan UMKM untuk mengembangkan usaha dan bisa meningkatkan tingkat pendapatan masyarakat.

Target kegiatan dan sasaran kegiatan ini bagi masyarakat adalah

a. Memperoleh bantuan tenaga dan pikiran untuk merencanakan serta melaksanakan pembangunan masyarakat di Daerah Aliran Sungai Citarum.

b. Memperoleh cara-cara (baru) di bidang ilmu, teknologi dan seni yang dibutuhkan untuk merencanakan dan melaksanakan pembangunan.

c. Memperoleh pengalaman, cara berpikir, bersikap dan bertindak untuk menggali dan menumbuhkan potensi swadaya masyarakat sehingga mampu berpartisipasi aktif dalam pembangunan.

d. Memperoleh pembaharuan - pembaharuan yang sangat beguna bagi kehidupan masyarakat.

\section{Metode}

Metode kegiatan ini sosialisasi kepada Masyarakat di desa Margaasih, Bandung, Jawa Barat. Setelah diberi pembinaan selanjutnya mereka dibimbing untuk menerapkan dalam rangka meningkatkan ekonomi desa. Berikut ini adalah tahapan pelatihan yang dilakukan.

1. Tahap Persiapan

Tahap persiapan pelatihan yang dilakukan meliputi: Survey, Pemantapan dan penentuan lokasi dan sasaran, dan Penyusunan bahan/materi. Persiapan yang dilakukan 
sebelum pelaksanaan program KKN Tematik Citarum Harum 2019, yaitu praktikan mempersiapkan diri menyusun program berdasarkan hasil observasi yang telah dilakukan sebelumnya pada program pra KKN. Program disusun sesuai dengan kebutuhan agar dapat terlaksana dengan terarah dan terorganisir.

Pembekalan KKN dilaksanakan di Universitas Majalengka yang telah ditentukan oleh Pusat Penelitian dan Pengabdian Masyarakat (P3M) Universitas Majalengka dan menentukan Dosen Pembimbing Lapangan (DPL). Pembekalan ini diadakan dengan tujuan agar mahasiswa: 1) Memahami dan menghayati konsep dasar, arti, tujuan, pendekatan program, pelaksanaan, monitoring, dan evaluasi. 2) Mendapatkan informasi tentang situasi, kondisi, potensi, dan permasalahan masyarakat. 3) Memiliki bekal pengetahuan tata krama kehidupan di masyarakat. 4) Memiliki wawasan tentang pengelolaan dan pengembangan lembaga pendidikan. 5) Memiliki bekal pengetahuan dan keterampilan praktis agar dapat melaksanakan program di masyarakat. 6) Memiliki pengetahuann untuk dapat bersikap dan bekerja dalam kelompok secara interdisipliner dan lintas sektoral dalam rangka penyelesaian program kerja di masyarakat. 7) Memiliki kemampuan menggunakan waktu secara efisien pada saat melaksanakan program KKN.

Pembekalan dengan DPL KKN-Tematik dilaksanakan sebelum dan selama KKN berlangsung, artinya pembekalan tidak hanya dilaksanakan sebelum KKN berjalan, tetapi juga selama KKN berlangsung, mahasiswa berhak untuk tetap berkomunikasi dan berkonsultasi dengan dosen pembimbing masing-masing.

Sasaran dari kegiatan KKN adalah kondisi fisik dan non fisik masyarakat. Penyerahan mahasiswa KKN- Tematik Citarum Harum 2019 ke masyarakat tempat pelaksanaan KKN dilaksanakan tanggal 16 Oktober 2019. Observasi ini mencakup pengamatan kondisi fisik, non fisik, dan kondisi masyarakat. Adapun kondisi non fisik di masyarakat, yaitu potensi masyarakat.

Setelah melakukan observasi potensi masyarakat yang mencakup kondisi fisik dan non fisik, mahasiswa melakukan identifikasi masalah yang dihadapi. Hasil dari pengamatan tersebut, dirumuskan menjadi program-program KKN yang akan dilaksanakan dan diharapkan dapat memberikan manfaat bagi masyarakat Dusun Santan.

Sebelum pelaksanaan program KKN, mahasiswa merencanakan untuk membuat program yang akan dilaksanakan berdasarkan urgenitas dan pertimbangan yang telah dijelaskan sebelumnya pada bab I. Seluruh program KKN merupakan tanggung jawab seluruh anggota, namun untuk lebih memudahkan koordinasi dan pelaksanaan program, diadakan pembagian tugas. Merumuskan program kerja sebagai hasil observasi lapangan yang dilaksanakan dari tanggal 14 dan 15 Oktober 2019, melaksanakan koordinasi dengan Danyon dan dosen pembimbing lapangan, kepala Desa Mekar Rahayu Kecamatan Margaasih Kabupaten Bandung mengenai rumusan program dan penentuan program kerja KKN selama proses observasi-penerjunan.

2. Tahap Pelaksanaan pembinaan

Tahap pelaksanaan pembinaan dilakukan setelah persiapan. Dalam tahap ini dilakukan pertama, pemberian motivasi agar masyarakat di desa tersebut dapat memperoleh bantuan tenaga dan pikiran untuk merencanakan serta melaksanakan pembangunan masyarakat di Daerah Aliran Sungai Citarum, memperoleh cara-cara (baru) di bidang ilmu, teknologi dan seni yang dibutuhkan untuk merencanakan dan 
melaksanakan pembangunan, memperoleh pengalaman, cara berpikir, bersikap dan bertindak untuk menggali dan menumbuhkan potensi swadaya masyarakat sehingga mampu berpartisipasi aktif dalam pembangunan, memperoleh pembaharuanpembaharuan yang sangat beguna bagi kehidupan masyarakat.

3. Metode Pelatihan, Tanya Jawab, dan Latihan atau Praktek

Metode ceramah dipilih untuk menyampaikan pengetahuan tentang pembangunan masyarakat. Metode tanya jawab sangat penting bagi para peserta, baik di saat menerima pengetahuan, serta di saat mempraktekkannya. Metode ini memungkinkan kesulitankesulitan ataupun masalah-masalah yang dihadapi dapat dipecahkan.

\section{Hasil dan Pembahasan}

Pelaksanaan program kerja KKN merupakan bentuk realisasi dari rancangan agenda yang tercantum dalam matriks program kerja. Idealnya, dalam pelaksanaan program kerja tersebut semestinya sesuai dengan yang terjadwal pada matriks program kerja. Namun, terkadang terdapat kendala dan hambatan yang membuat realisasi dari program kerja yang diagendakan tidak sesuai dengan yang dijadwalkan. Berikut ini adalah pembahasan program kerja yang sudah dilaksanakan:

Kemajuan Program kegiatan berjalan mulai 16 Oktober 2019 hingga 7 November 2019 di Desa Mekar Rahayu Kecamatan Margaasih Kabupaten Bandung. Adapun uraian mengenai keterlaksanaan program diuraikan seperti di bawah ini:

Melakukan bakti sosial dengan menaman pohon Buah Nangka dan pohon Petay. Kegiatan penanaman pohon di maksud mendorong masyarakat akan pentingnya menanam pohon. Tujuan dari pada Penanaman pohon ini adalah : 1) Mengurangi dampak pemanasan Global; 2) Meningkatkan absorbsi gas $\mathrm{CO}_{2}$, dan polutan lainnya; 3) Mencegah banjir, kekeringan dan tanah longsor; 4) Meningkatkan upaya konversi sumberdaya genetik tanaman hutan; 5) Meningkatkan kesadaran masyarakat untuk menanam dan memelihara tanaman

Kegiatan ini di laksanakan minggu ke-3 Pelaksanaan KKN-Tematik. Secara Prinsip dalam pelaksanaan Kegiatan Temu Warga dan Penanaman Pohon Nangka dan Petai tidak ada kendala. Antus masyarakat, Pemerintahan Desa, BPD, dan unsur lain saling membantu dan bekerja sama dalam pelaksanaan kegiatan. Masyarakat desa di Daerah aliran sungai Citarum yaitu: 1) Pemerintahan Desa Mekar Raharja; 2) Pegiat Lingkungan "Sabilulungan Bersih Rereongan" (SABER) Desa Mekar Rahayu; 3) Anggota BPD Desa Mekar Rahayu Kecamatan Margaasih; 4) Anggota Satgas Sektor 8 Margaasih; 5) Siswa SMAN 01 Margaasih; 6) Masyarakat RW 03 Desa Mekar Rahayu; 7) Mahasiswa dan DPL Universitas Majalengka.

Hambatan pelaksanaan kegiatan KKN T Citarum Harum 2019 sedikit terkendala karena Desa Mekar Rahayu sedang melaksanakan Pemilihan Kepala Desa serentak. Kendala pelaksanaan kegiatan lebih bersifat non teknis kondisi di Desa Mekar Rahayu. Berdasarkan masukan dan arahan pada saat koordinasi dengan Pemerintahan Desa dan Satgas Sektor 8 Margaasih pelaksanaan kegiatan yang efektif setelah pemilihan kepada Desa, diantaraynya adalah lokasi penanaman pohon di arahkan pada lokasi daerah sepadan aliran sungai, meningkatnya pengetahuan dan pemahaman warga desa daerah aliran sungai citarum tentang pentingnya penanaman pohon yang di ikuti dengan 
keikutsertaan warga masyarakat dalam program penanaman pohon, Lingkungan semakin rindang dengan nilai estetika bertambah dengan banyaknya pohon yang di tanam.

Dosen DPL , Mahasiswa, Pemerintahan Desa Mekar Rahayu, Tokoh Masyarakat, Tokoh Agama dan Lainnya dengan Melakukan Penanaman Pohon serta alat-alat pertanian

\section{Kesimpulan}

Kesimpulan yang diperoleh dari program ini, adalah:

1) masyarakat Desa Mekar Rahayu Kecamatan Margaasih Kabupaten Bandung optimisme masyarakat dalam mengembangkan desa.

2) masyarakat Desa Mekar Rahayu Kecamatan Margaasih Kabupaten Bandung lebih kreatif dan positif dalam menata masa depan.

3) kualitas sumber daya manusia yang berlandaskan Gotong Royong, Persatuan dan Kesatuan dalam Wadah Negara Kesatuan Republik Indosnesia.

5) motivasi masyarakat meningkat untuk berpartisipasi aktif dalam pembangunan, kepekaaan sosial dan penanganan persoalan-persoalan di Daerah Aliran Sungai Citarum

\section{Daftar Pustaka}

Undang-undang No.22 Tahun 1999 tentang Pemerintahan Daerah

Fida, A. dkk. (1997). Pedoman Pelaksanaan Kuliah Kerja Nyata (KKN). Rineka Cipta. Jakarta

Gunawan, Ary H. 2000. Sosiologi Pendidikan. Jakarta: Rineka Cipta.

Hermansyah, A. (2018). Pembangunan Infrastruktur dan Partisipasi Masyarakat. Diakses 19 Februari 2020 dari https://news.detik.com/kolom/d-4021236/pembangunaninfrastruktur-dan-partisipasi-masyarakat. 